neuronal activity in the locus coeruleus ${ }^{5-7}$ and decreased noradrenaline release. ${ }^{8,9}$ While clonidine and the opiates have similar effects on the locus cœruleus, clonidine appears to exert specific effects through non-opiate, alpha-2 adrenergic receptors. ${ }^{6.7}$ These data suggested that the opiate-withdrawal syndrome is due to increased noradrenergic neuronal activity in areas such as the locus cœruleus which are regulated both by alpha- 2 adrenergic and opiate receptors.

Our preliminary results in man support a noradrenergic system mediation of opiate withdrawal and suggest that clonidine may be a more definitive treatment for opiate withdrawal than others now available.

Department of Psychiatry

and Connecticut Mental Health Center,

Yale University School of Medicine,

New Haven, Connecticut 06510, U.S.A.

MARK S. Gold

D. E. REDMOND, JR

H. D. KLEBER

\section{HI.A AND CONGENITAL ADRENAL HYPERPLASIA LINKAGE CONFIRMED}

SIR,-Congenital adrenal hyperplasia (C.A.H.) is an autosomal recessive disease, associated in most cases with 21-hydroxylase deficiency. ${ }^{1,2}$ Dupont et al. ${ }^{3}$ suggested that the locus responsible for 21-hydroxylase deficiency is in close linkage with the HLA system. We have typed six families with one or more children with C.A.H. and report data supporting this linkage (table).

HLA typing was done by the standard two-stage National Institutes of Health lymphocytotoxicity test. 118 different sera were used to detect HLA A, B, and C antigens with the exception of CW6. In all families in which the segregation of W4 and W6 could be determined these antigens behaved as expected. In all families the segregation of the HLA haplotypes was established. Seven children with C.A.H. confirmed biochemically to be due to 21-hydroxylase deficiency were studied. The salt-losing form of 21-hydroxylase deficiency was present in four families while the remaining families ( $\mathrm{A}$ and $\mathrm{E}$ ) had the non-salt-losing form.

5. Svensson, T. H., Bunney, B. S., Aghajanıan, G. K. Brain Res. 1975, 92, 291.

6. Cedarbaum, J. M., Aghajanian, G. K. ibid. 1976, 112, 413.

7. Cedarbaum, J. M., Aghajanian, G. K. Eur. F. Pharmac. 1977, 44, 375.

8. Braestrup, C. F.Pharm. Pharmac. 1974, 26, 139.

9. Maas, J. W., Hattox, S. E., Landis, D. H., Roth, R. H. Brain Res. 1976, 118, 167.

1. Bongiovanni, A. M., Root, A. W. New Engl. J. Med. 1963, 268, 1283.

2. New, M. I., Levine, L. S. in Advances in Human Genetics (edited by K. Hirschhorn and H. Harris); p. 251. New York, 1973.

3. Dupont, B., Oberfield, S. E., Smithwick, E. M., Lee, T. D., Levine, L. S. Lancet, 1977, ii, 1309.
In family $B$ both children had the HLA haplotype A3, BW47. The children seemed to be HLA homozygous although the parents were not first cousins and denied any known consanguinity. Family A was ascertained through child 5, a girl with C.A.H. The HLA typing of the family showed that her oldest brother was HLA identical. This 23-year-old man was further investigated and on both clinical and biochemical grounds was considered to be homozygous for 21-hydroxylase deficiency. Thus, the diagnosis was first suggested by HLA typing and then confirmed by clinical and biochemical studies (this case will be discussed in greater detail elsewhere). In a Pakistani family (F) the parents were first cousins and the only affected child was an HLA homozygote. In this family, child 4 carried a maternal HLA A/C,B recombinant haplotype while inheriting the same paternal haplotype as the affected sib. Thus, the two children ( 4 and 5) are HLA indentical at the A locus but different at the $C, B$ loci showing that the gene for C.A.H. segregated with HLA-B rather than with HLA-A since child 4 "escaped" 21-hydroxylase deficiency. In three families (C, D, and E) with two children discordant for 21-hydroxylase deficiency the affected and unaffected children were not HLA identical.

In our families and those of Dupont et al. ${ }^{3}$ no recombination between the HLA-B locus and the gene for C.A.H. has been found in a total of 35 children (or a total of 40 meiotic divisions including the family $\mathrm{F}$ first cousins). However, two recombinants between HLA $A$ and $B$ have been found in the twelve families. No association between particular HLA antigens and 21-hydroxylase deficiency gene occurred.

These findings have implications for both prenatal and postnatal diagnosis of 21-hydroxylase deficiency. Biochemical tests, though encouraging, have not yet provided unequivocal means of diagnosis in fetal life. ${ }^{4}$ If diagnosis proves possible by the HLA typing of amniotic cells taken in the second trimester, it will allow parents with a previous previously affected child the opportunity to consider selective abortion. The ethics of abortion of a fetus with a condition amenable to postnatal treatment and compatible with life must be carefully considered. Unequivocal diagnosis in early pregnancy would make the more positive goal of prenatal treatment to prevent clitoral enlargement more feasible. HLA types of amniotic cells in late pregnancy or of cord-blood lymphocytes would supplement biochemical studies and allow early diagnosis and prompt treatment. Finally, identification of heterozygotes can be made with greater certainty thus facilitating the study of the carrier

4. New, M. I. in Congenital Adrenal Hyperplasia (edited by P. A. Lee, L. P. Plotnick, A. A. Kowarki, and C. J. Migeon); vol. I, p. 511. Baltimore, 1977.

HLA GENOTYPES IN SIX FAMILIES WITH C.A.H.

\begin{tabular}{|c|c|c|c|c|c|c|c|c|}
\hline \multirow[b]{2}{*}{ Family } & \multirow[b]{2}{*}{ Parents } & \multirow[b]{2}{*}{ HLA haplotypes } & \multicolumn{6}{|c|}{ Children: HLA haplotypes } \\
\hline & & & 1 & 2 & 3 & 4 & 5 & 6 \\
\hline B & $\begin{array}{l}\text { F A3,Bw47/A2,B12 } \\
\text { M A3,Bw47/A?.B7 }\end{array}$ & $\begin{array}{l}a / b \\
c / d\end{array}$ & $\mathrm{a} / \mathrm{c}^{\star}$ & $a / c^{\star}$ & & & & \\
\hline C & $\begin{array}{l}\text { F A11,Bw } 22, \mathrm{Cw} 3 / \mathrm{A} 11, \mathrm{~B} 27, \mathrm{Cw} 2 \\
\mathrm{M} \mathrm{A} 3, \mathrm{~B} 40 / \mathrm{A} 2, \mathrm{~B} 17, \mathrm{Cw} 5\end{array}$ & $\begin{array}{l}a / b \\
c / d\end{array}$ & $a / c^{\star}$ & $\mathrm{b} / \mathrm{d}$ & & & & \\
\hline $\mathrm{D}$ & $\begin{array}{l}\text { F A2,Bw35,Cw4/A29,B-,Cw } 5 \\
\text { M A2,B12/A1,B8,Cw5 }\end{array}$ & $\begin{array}{l}a / b \\
c / d\end{array}$ & $a / c^{\star}$ & $\mathrm{b} / \mathrm{d}$ & & & & \\
\hline $\mathrm{E}$ & $\begin{array}{l}\text { F A10,B27,Cw1/A1,B8 } \\
M \quad \mathrm{~A} 3, \mathrm{~B} 7 / \mathrm{A} 9, \mathrm{~B} 12, \mathrm{Cw} 4\end{array}$ & $\begin{array}{l}a / b \\
c / d\end{array}$ & $\mathrm{a} / \mathrm{d}$ & $a / c^{\star}$ & & & & \\
\hline $\mathrm{F}$ & $\begin{array}{l}\text { F A1,B5,/A10,B40 } \\
\text { M A1,B5/A11,Bw35,Cw4 }\end{array}$ & $\begin{array}{l}a / b \\
c / d\end{array}$ & $\mathrm{~b} / \mathrm{d}$ & $\mathrm{b} / \mathrm{d}$ & $\mathrm{b} / \mathrm{c}$ & $\mathrm{a} / \mathrm{cxd} \ddagger$ & $a / c^{\star}$ & \\
\hline
\end{tabular}

* Affected child. $†$ 21-hydroxylase deficiency homozygote, clinically normal (see text).

$\mp$ HLA recombinant: HLA-A1,-B5/A1, Bw35,Cw4.

$\mathrm{F}=$ father; $M=$ mother. 
state and distinguishing the mildly affected homozygote in difficult cases. ${ }^{5}$

Royal Manchester Children's Hospital

Department of Medical Genetics,

D. A. Price

St. Mary's Hospital,

Manchester $M 130 \mathrm{JH}$

P. T. KLOUdA

R. HARRIS

SiR,--We can confirm that the gene for adrenogenital syndrome (21-hydroxylase deficiency type) is closely linked to HLA, as reported by Dupont et al. ${ }^{1}$

Three kindreds (A, B, and C) were ascertained through a female child with raised urinary 17-ketosteroids and virilising adrenogenital syndrome. Two of the propositi have affected brothers (raised urinary 17-ketosteroids); all five children have responded to corticosteroids. Genetic marker data on the individuals in family $A$ have been reported previously as part of a study of a kindred with a chromosome abnormality. ${ }^{2}$ The abnormality has lately been determined to be a translocation $\mathfrak{t}(2 ; 10)(\mathrm{q} 21 ; \mathrm{q} 24)^{3}$ and is believed to be unrelated to adrenogenital syndrome. This family was HLA typed several years ago, with a limited range of HLA antisera. The results of typing the three kindreds for the closely linked chromosome 6 markers, ${ }^{4}$ HLA-A, HLA-B, Bf (properdin factor B), and red cell glyoxalase are shown in table $\mathrm{I}$.

A summary of lod scores ${ }^{5}$ (logarithm of the odds) for linkage of the HLA-B, Bf region with adrenogenital syndrome is shown in table II. Dupont et al. ${ }^{1}$ used $e_{1}$ corrections in the calculation of the scores in their families. We believe this is not appropriate in the calculation of lod scores for linkage of a recessive trait with a co-dominant, multiallelic marker such as HLA. Lod scores for the families of Dupont et al. have been recalculated directly from first principles, without corrections, and are presented in table $\mathrm{I}$. The recalculated peak lod score is 4.6 instead of 3.4. Since HLA-B and Bf are very closely linked, ${ }^{4}$ we have used information from both systems to determine the parental contribution of genes in this region of chromosome 6 in the three new families. Thus, the assignment of
5. Zachmann, M., Prader, A. 16th annual meeting of the European Society for Pædiatric Endocrinology; abstr. 91. 1977.

1. Dupont, B., Smithwick, E. M., Levine, L. S. Oberfield, S. E., Lee, T. D. Lancet, 1977, ii, 1309.

2. Weitkamp, L. R., Janzen, M. K., Guttormsen, S. A., Gershowitz, H. Ann. hum. Genet. $1969, \mathbf{3 3}, 53$.
3. Weitkamp, L. R., Ferguson-Smith, M. A., Guttormsen, S. A., Huntzinger, R. S., Chaganti, R. S. K., German, J., Schanfield, M. S. ibid. (in the press).

4. Weitkamp, L. R., Francke, U. Cytogenet. Cell Genet. (in the press).

5. Morton, N. E. Am. F. hum. Genet. 1955, 7, 277.

TABLE I-CHROMOSOME 6 HAPLOTYPES IN THREE FAMILIES WITH ADRENOGENITAL SYNDROME

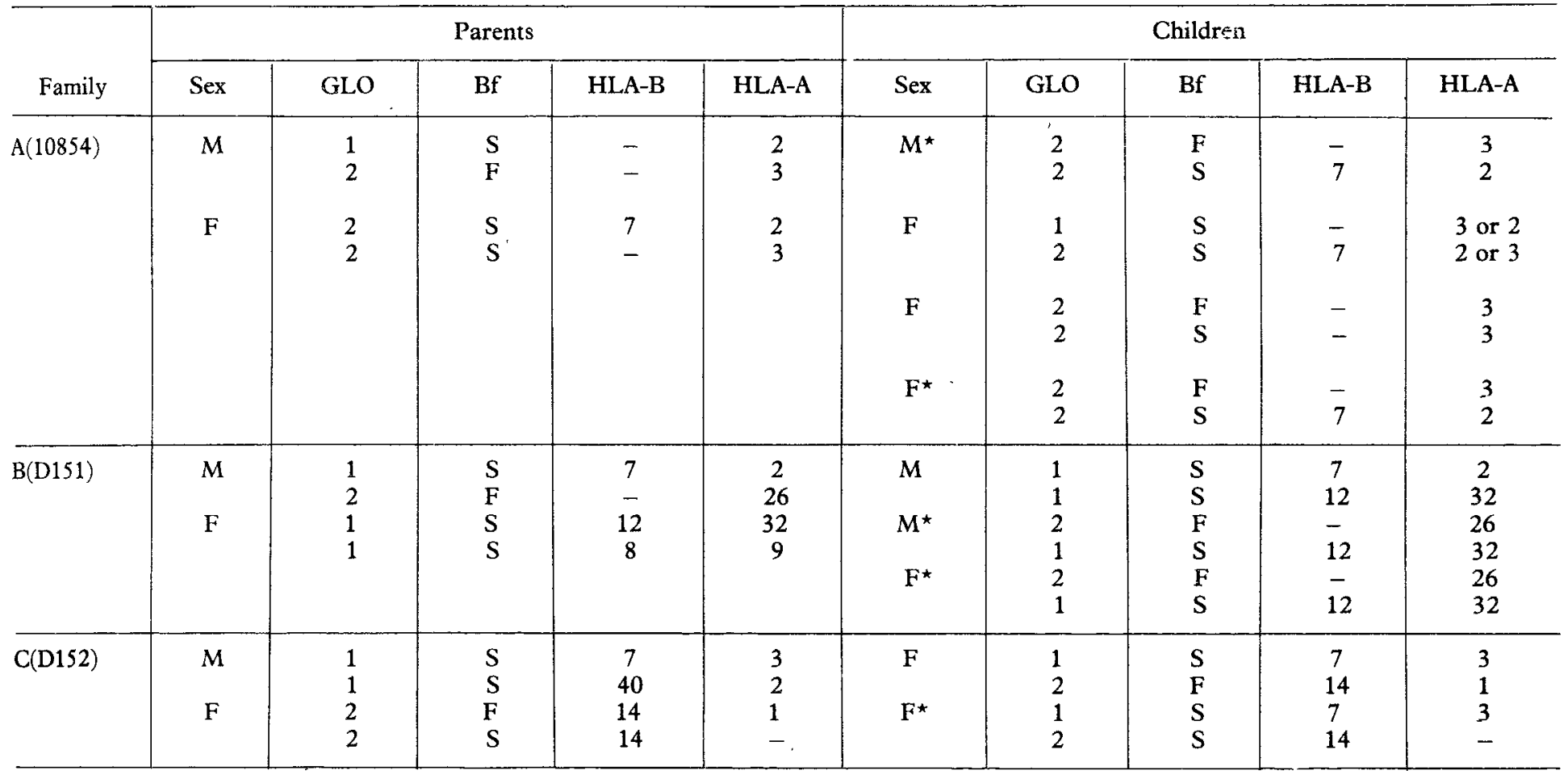

*Adrenogenital syndrome. GLO=red-cell glyoxalase.

TABLE II-LOD SCORES FOR LINKAGE BETWEEN HLA-B (OR Bf) AND ADRENOGENITAL SYNDROME (21-HYDROXYLASE DEFICIENCY A.G.S.)

\begin{tabular}{|c|c|c|c|c|c|c|c|c|}
\hline \multirow[b]{2}{*}{ Kindred ${ }^{\star}$} & \multirow{2}{*}{$\begin{array}{l}\text { Type of } \\
\text { A.G.S. }\end{array}$} & \multirow{2}{*}{$\begin{array}{c}\text { Chromosome } \\
6 \text { locus }\end{array}$} & \multicolumn{6}{|c|}{ Lod score for recombination fraction $(\theta)$ of: } \\
\hline & & & 0.00 & 0.01 & 0.02 & 0.03 & 0.04 & 0.05 \\
\hline $\begin{array}{l}1 \\
2 \\
3 \\
4 \\
5 \\
6 \\
\mathrm{~A} \\
\mathrm{~B} \\
\mathrm{C}\end{array}$ & $\begin{array}{c}\text { Salt losing } \\
\text { Salt losing } \\
\text { Salt losing } \\
\text { Salt losing } \\
\text { Compensated } \\
\text { Salt losing } \\
\text { Salt losing } \\
\text { Coinpensated } \\
\text { Salt losing }\end{array}$ & $\begin{array}{c}\text { HLA-B } \\
\text { HLA-B } \\
\text { HLA-B } \\
\text { HLA-B } \\
\text { HLA-B } \\
\text { HLA-B } \\
\text { HLA-B, Bf } \\
\text { HLA-B, Bf } \\
\text { HLA-B, Bf }\end{array}$ & $\begin{array}{l}0.602 \\
0.602 \\
0.602 \\
0.727 \\
1.329 \\
0.727 \\
0.852 \\
0.727 \\
0.288\end{array}$ & $\begin{array}{l}0.585 \\
0.585 \\
0.585 \\
0.705 \\
1.303 \\
0.710 \\
0.826 \\
0.705 \\
0.268\end{array}$ & $\begin{array}{l}0.567 \\
0.567 \\
0.567 \\
0.684 \\
1.276 \\
0.692 \\
0.800 \\
0.684 \\
0.249\end{array}$ & $\begin{array}{l}0.550 \\
0.550 \\
0.550 \\
0.662 \\
1.249 \\
0.675 \\
0.773 \\
0.662 \\
0.231\end{array}$ & $\begin{array}{l}0.533 \\
0.533 \\
0.533 \\
0.640 \\
1.222 \\
0.657 \\
0.746 \\
0.640 \\
0.214\end{array}$ & $\begin{array}{l}0.515 \\
0.515 \\
0.515 \\
0.618 \\
1.194 \\
0.639 \\
0.721 \\
0.618 \\
0.198\end{array}$ \\
\hline & . & $\ldots$ & 6.456 & $6 \cdot 272$ & 6.086 & 5.902 & $5 \cdot 718$ & 5.533 \\
\hline
\end{tabular}

*Families $1-6$ of Dupont et al. 
adrenogenital syndrome to the HLA region is confirmed with a total peak lod score $>6$ (odds of $10^{6}: 1$ ) at $\frac{1}{2} \sim 0.00$.

Two additional conclusions may be drawn from these data. First there is no evidence that the genes for the salt-losing and compensated forms of adrenogenital syndrome have a different linkage distance to HLA-B. Second, Dupont et al. observed that adrenogenital syndrome is on the HLA-B side of HLA-A, basing the suggestion on a single family with an HLA-B: HLA-A recombinant. Child 2 in our family $A$ is either a paternal Bf:HLA-A recombinant or a maternal HLA-B:HLA-A recombinant. In the former case the adrenogenital syndrome gene segregates with $\mathrm{Bf}$, and in the latter the gene segregates with HLA-B, confirming, in either event, that the gene for the adrenogenital syndrome is on the HLA-B side of HLA-A.

There is no evidence for association of the gene(s) for adrenogenital syndrome with a specific HLA-B allele in the nine reported families; thus, the HLA-B and adrenogenitalsyndrome loci are apparently far enough apart for linkage disequilibrium not to be prominent. The adrenogenital syndrome locus (loci) may lie as much as a few centimorgans from HLA-B. More precise mapping will be possible when red-cellglyoxalase: HLA recombinants are found in families with the adrenogenital syndrome.

Department of Psychiatry and Pediatrics,

Division of Genetics,

University of Rochester School of Medicine and Dentistry, Rochester, N.Y. 14642, U.S.A

\section{R. WEITKAMP}

Department of Pediatrics,

University of Rochester School of Medicine and Dentistry M. BRYSON

Department of Pediatrics and Communicable Diseases,

University of Michigan Medical School,

Ann Arbor, Michigan

G. E. BACON

\section{PRENATAL DIAGNOSIS OF PRIMARY PITUITARY DYSGENESIS}

SIR, - Primary pituitary dysgenesis is a rare inherited disease in which where we may find hypoglycæmia, respiratory distress, small sella turcica, hypothyroidism, adrenal insufficiency, and ectopic testes. ${ }^{1,2}$

We have attempted prenatal diagnosis in two pregnancies at risk for primary pituitary dysgenesis. These were the 5 th and 6 th pregnancies. The results of the 1 st and the 4 th were normal girls. The other two gave affected boys. ${ }^{1,2}$ The parents are cousins.

Prolactin activity was measured in amniotic fluid obtained at 16 weeks' gestation. Amniotic fluid was frozen until analysed. Prolactin activity was measured in 20 amniotic fluids from controls at the same gestational age. Prolactin was measured by double-antibody radioimmunoassay. ${ }^{3}$ Prolactin levels were low $(355 \mathrm{ng} / \mathrm{ml})$ in the 5 th pregnancy. The parents wanted to continue the pregnancy; the result was an affected boy. In the 6th pregnancy prolactin levels were normal (1500 $\mathrm{ng} / \mathrm{ml}$ ).

Clements et al. ${ }^{4}$ found that prolactin levels in amniotic fluid averaged $1314 \mathrm{ng} / \mathrm{ml}$ (range 270-2950) at 15-17 weeks. None of our controls had a prolactin level at 16 weeks fetal age under $1337 \mathrm{ng} / \mathrm{ml}$ (range 1337-2487).

The 6th pregnancy was continued and a normal girl was born. She is now 6 months old, and hormone studies, X-rays of the sella turcica, and bone age are normal. Serum-prolactin was measured at 2 days of age and found to be $202 \mathrm{ng} / \mathrm{ml}$ (term cord-blood values averaged $199 \mathrm{ng} / \mathrm{ml}$ ).

Prenatal diagnosis of primary pituitary dysgenesis early

1. Willard, D., and others. Nouv. Presse méd. 1972, 1, 2237.

2. Willard, D., Messer, J., Freysz, H. Archs ft Pediat 1974, 31, 347.

3. Hwang, P., Guyda, H., Friesen, H. Proc. natn. Acad. Sci. U.S.A. 1971, 68, 1902

4. Clements, J. A., Reyes, F. I., Winter, J. S. D., Faiman, C. $\mathcal{f}$. clin. Endocr. Metab. 1977, 44, 408 . enough to give the parents of an affected fetus the choice of termination of pregnancy now seems possible.

Service de Pédiatrie 5,

Centre Hospitalier Universitaire, C. STOLL

67000 Strasbourg, France $\quad$ D. WILLARD

Hôpital des Enfants Malades,

Paris

P. Czernichow

Groupe de Recherches de Biologie Prénatale,

Paris

J. BOUE

\section{CIMETIDINE MAINTENANCE: HOW LONG?}

SiR,-Dr Blackwood and colleagues (March 25, p. 626) found that nearly all duodenal ulcers which had been healed by an initial course of cimetidine relapsed if not further treated ( 21 out of 24 placebo-treated patients had recurrent duodenal ulcers within six months of initial healing) while only 5 out of 21 patients had ulcer recurrences during a six-month period of treatment with bedtime cimetidine. Blackwood et al. conclude that bedtime cimetidine prevents relapse of duodenal ulcers.

Almost identical suppression of the tendency of duodenal ulcers to relapse has been noted with two different cimetidine maintenance regimens studied in unpublished trials done in Nottingham (and Lincoln) and Dundee. In Nottingham twice daily cimetidine $(400 \mathrm{mg}$ morning and night) resulted in a relapse-rate of only $25 \%$ after six months; $75 \%$ of ulcers which had healed after an initial course of cimetidine, relapsed within six months during treatment with placebo. In Dundee $98 \mathrm{pa}-$ tients were maintained in full doses of cimetidine $(200 \mathrm{mg}$ three times daily after food and $400 \mathrm{mg}$ at night) for three to twelve months after primary healing of the duodenal ulcers. The recurrence-rate was $19 \%$. Thus cimetidine not only heals most duodenal ulcers but also it usually prevents relapse of healed ulcers when treatment with the drug is continued for six to twelve months.

Unfortunately Blackwood et al. do not say what happened to their patients after maintenance treatment with cimetidine was stopped. In Nottingham a further $40 \%$ of the cimetidinetreated patients relapsed during eight months after cessation of maintenance treatment, raising the rate of recurrence to about $70 \%$. In Dundee follow-up for nearly two years after the end of maintenance treatment revealed relapse in a further $44 \%$, giving a rate of relapse during and after treatment of $63 \%$. It is not clear whether these overall relapse-rates differ significantly from the rate of relapse of placebo-treated patients, so we still do not know how long we need to treat patients with cimetidine before we can be sure that we are not merely deferring their visit to the surgeon.

Department of Therapeutics,

City Hospital,

Nottingham NG5 1PB

M. J. S. LANGMAN

Department of Therapeutics,

Ninewells Hospital, Dundee, DD2 1UB $\quad$ K. G. WormsLeY

\section{HB $_{\mathrm{s}}$ Ag IN SUPERFICIAL ARTERY OF PATIENT WITH POLYMYALGIA RHEUMATICA}

SIR,- - Liver enzyme and other functional abnormalities in polymyalgia rheumatica are well known. Corticosteroid therapy rapidly reverses these anomalies. ${ }^{1,2}$ Liver biopsy usually reveals normal parenchyma or fatty degeneration, ${ }^{1,3}$ but in one case granulomatous hepatitis associated with fatty degeneration and thickening of the walls of small intrahepatic arteries has been reported. ${ }^{4}$

Hepatitis $\mathrm{B}$ antigen $\left(\mathrm{HB}_{\mathrm{s}} \mathrm{Ag}\right)$ has never been found in cases

\footnotetext{
1. Dickson, E. R., Maldonado, J. E., Sheps, S. G., Cain, J. A. Jr. f. Am. med Ass. 1973, 224, 1496.

2. Glick, E. N. Lancet, 1972, ii, 328.

3. Terwindt, V. A. M., Knoben, J. M. A. M. Acta med. scand. 1966, 179, 307
}

4. Long, R., James, O. Lancet, 1974, i, 77. 